\title{
Histopathology of Carp (Cyprinus carpio L.) Larvae Exposed to Cyanobacteria Extract
}

\author{
M. PALÍKOVÁ ${ }^{1}$, S. NAVRÁTIL ${ }^{1}$, F. TICHÝ $^{3}$, F. ŠTĚRBA $^{2}$, B. MARŠÁLEK ${ }^{4}$, L. BLÁHA $^{5}$ \\ ${ }^{1}$ Department of Veterinary Ecology and Environmental Protection, ${ }^{2}$ Department of Biology and Wildlife \\ Diseases, ${ }^{3}$ Department of Anatomy Histology and Embryology, \\ University of Veterinary and Pharmaceutical Sciences, Brno, Czech Republic \\ ${ }^{4}$ Institute of Botany, Academy of Sciences of the Czech Republic, Brno, Czech Republic \\ ${ }^{5}$ RECETOX, Masaryk University, Brno, Czech Republic
}

Received June 27, 2003

Accepted February 11, 2004

\begin{abstract}
Palíková M., S. Navrátil, F. Štěrba, F. Tichý, B. Maršálek, L. Bláha: Histopathology of Carp (Cyprinus carpio L.) Larvae Exposed to Cyanobacteria Extract. Acta Vet. Brno 2004, 73: 253-257.

The aim of this study was to examine histological changes of tissues of carp embryos and larvae exposed for a short-term ( 8 days) or a long-term (30 days) to the crude extract of cyanobacteria with the cumulative concentration of $130.0 \mu \mathrm{g} \cdot 1^{-1}$ (high concentration of the extract), $13.0 \mu \mathrm{g} \cdot \mathrm{l}^{-1}$ (medium concentration of the extract) and $1.3 \mu \mathrm{g} \cdot \mathrm{l}^{-1}$ (low concentration of the extract) of microcystins LR, RR and YR. The concentration of $130.0 \mu \mathrm{g} \cdot \mathrm{l}^{-1}$ was used only for the short-term exposure. Tissue sections were stained with haematoxylin-eosin and PAS and examined using light microscopy. Apoptotic cells were detected by TUNEL test. Changes of liver and kidney, in particular, were examined. No histopathological changes were found in control or experimental groups after the short-term exposure except for non-resorbed yolk sacks in the group exposed to the high concentration of the extract. The development had been retarded in this group. Vacuolar dystrophy of hepatocytes accompanied by damage of nuclei (pyknosis, karyolysis) were found after the long-term exposure in the group exposed to the low concentration of the extract. Focal necroses and dystrophic changes of hepatocytes with vacuolization and nuclei damage (pyknosis, karyolysis, hyperchromatosis, karyorrhexis) were found in the group exposed to the medium concentration of the extract for a long term. Apoptotic cells were detected in the liver. No changes were found in the kidney. The results documented the damage of liver tissue in larval stages of carp exposed to the crude extract of cyanobacteria in early life stages of development. The degree of damage depended on the concentration of the extract.
\end{abstract}

Microcystins, embryo-larval test, liver damage, fish, apoptotic cells

Cyanobacteria are a common and natural component of most water ecosystems. Mass development of cyanobacteria closely correlates with eutrophication of waters. The development of cyanobacterial water blooms decreases water quality from viewpoint of water management, hygiene and fishery.

Cyanobacteria can produce and incidentally release in to their environment substances having a biological activity such as enzymes, vitamins, toxins, extracellular polysaccharides, attractants, amino acids and other organic acids, antibiotics and hormones. These substances can influence growth and development of other water organisms. Toxins of the blue-green algae may be divided according to various points of view. Carmichael (1992) divides the cyanotoxins according to methods of detection into cytotoxins and biotoxins. The biotoxins may be classified according to their biological activities as neurotoxins, hepatotoxins, cytotoxins, genotoxins, immunotoxins and embryotoxins. Population of a single species of blue-green algae may produce several toxins (Maršálek and Turánek 1996). Hepatotoxins are most common and frequently involved in acute toxicoses. They damage the structure and function of liver. They are structurally cyclic and 
heat-resistant peptides. Well known hepatotoxins are microcystins, microviridins, nodularin and cylindrospermopsin (Maršálek and Turánek 1996). Microcystin LR is the most common and most often studied hepatotoxin. The mechanism of its influence is on cellular level (Eriksson 1990). More than 60 congeners of microcystins are known at present (Fis cher et al. 2001). Microcystins are cyclic heptapeptides. They have hepatotoxic effect. Many authors examined the histopathological findings and the mechanism of influence of microcystins. Deformation of hepatocytes is the most pronounced effect (Runnegar and Falconer 1986; Falconer and Yeung 1992). Falconer and Yeung (1992) concluded that the mechanism of microcystin toxicity to the hepatocyte is through cytoskeletal damage leading to loss of cell morphology, cell to cell adhesion and finally cellular necrosis. This structural damage manifests as intrahepatal haemorrhages (Falconer et al. 1983). Liver insufficiency develops in long-term surviving individuals (Beasley et al. 1989). The organotropism of microcystin LR manifests clearly on the cellular level and is specific for hepatocytes. Toxicity of microcystin LR in vivo primarily consists in the hepatocellular deformation inducing degenerative changes of the tissue (Eriksson et al. 1987, 1988ab, 1989).

Recently, research into this area has also been aimed at the evaluation of effects of cyanotoxins to the early life stages of organisms. The effect of microcystins and the crude extract of cyanobacteria on the development of fish and amphibians were studied (Oberemm et al. 1997, 1999; Wiegand et al. 1999) without description of histopathology of fish embryos and larvae. Ultrastructural changes in hepatocytes of posthatching loach larvae after exposure to microcystin LR were described by Liu et al. (2002). These authors described deformation of nucleus, moving of nuclei to the side of nuclear membrane, convolution of the nuclear membrane, vesiculation of the rough endoplasmic reticulum, reduction and transformation of RER into concentric membrane whorls. Ultrastructural alteration also occurred in the heart - fibrillation of the heart muscle and deformation of erythrocytes.

The level of dissolved microcystins in the Czech Republic measured in drinking water reservoirs, recreational reservoirs and fish pond with Microcystis ichthyoblabe dominance amounted to $0-45 \mu \mathrm{g} \cdot \mathrm{l}^{-1}, 0-180 \mu \mathrm{g} \cdot \mathrm{l}^{-1}$ and $225 \mu \mathrm{g} \cdot \mathrm{l}^{-1}$, respectively (Bláha and Maršálek 2001). The concentrations of microcystins in the cyanobacterial biomass from Czech water bodies vary from 0 to $4450 \mu \mathrm{g} \cdot \mathrm{g}^{-1}$ of dry weight (Maršálek et al. 2001).

Histopathology of carp larvae exposed to the crude extract of cyanobacteria after embryonal (short-term) and embryo-larval (long-term) tests are presented in this study. The concentrations of microcystins were chosen by comparison with literature and with the level of dissolved microcystins in natural waters in the Czech Republic.

\section{Materials and Methods}

The carp eggs were obtained by stripping at the fishery in Oslavany (Czech Republic). Fertilised and unsticked carp eggs were divided into eight groups, each containing two hundred eggs. The eggs were incubated in glass vials containing 0.51 of water. The bath was changed every 8 hours. The conditions in baths were following: water temperature $21.5-22.5^{\circ} \mathrm{C}$, dissolved oxygen $65-113 \%$ (i.e., $5.5-10.1 \mathrm{mg} \cdot \mathrm{l}^{-1}$ ) and $\mathrm{pH} 7.9-8.9$.

The larvae were been fed by nauplii of the brine shrimp Artemia salina (commercially delivered as Artemia PREMIUM) since the $5^{\text {th }}$ day. Feeding was performed 20-30 minutes before every bath change.

The tests were performed with the crude cell extract obtained from terrain samples of water bloom (Brno reservoir, Czech Republic). The sample contained the planktonic species of M. aeruginosa (85\%), Microcystis ichthyoblabe $(5 \%)$ and Aphanizomenon flos-aquae $(3 \%)$. The sample was collected from the surface water bloom $(0$ to $0.3 \mathrm{~m}$ depth) and concentrated by a plankton net of $22 \mu \mathrm{m}$. The sample was stored frozen at $-20^{\circ} \mathrm{C}$. The concentration of microcystins was determined by HPLC according to the method described by Law ton et al. (1994). The total microcystin concentration (MC) was $1129 \mu \mathrm{g} \cdot \mathrm{g}^{-1}$ of dry weight in the biomass. To obtain the crude extract, the material was ultrasonicated for 7 minutes and centrifuged for 20 minutes at $5000 \mathrm{rpm}$. Re-extraction was done twice by standard water. The final concentration of hepatotoxic microcystins in the crude extract used for the exposure was $15.7 \mu \mathrm{g} \cdot 1^{-1}\left(9.6 \mu \mathrm{g} \cdot 1^{-1}\right.$ of microcystin YR, $6.0 \mu \mathrm{g} \cdot 1^{-1}$ of microcystin LR, $0.1 \mu \mathrm{g} \cdot 1^{-1}$ of microcystin RR). The 
amount of the biomass was $22.1 \mu \mathrm{g} \cdot \mathrm{g}^{-1}$ of dry weight. These biomass concentrations commonly occur in the Brno reservoir (Czech Republic).

The number of eggs in each group was 200. The crude extract of cyanobacteria was added to the water at three concentrations: $0.5 \mu \mathrm{g} \cdot 1^{-1}$ of microcystin LR (low concentration of the extract), $5.0 \mu \mathrm{g} \cdot \mathrm{l}^{-1}$ of microcystin LR (medium concentration of the extract) and $50.0 \mu \mathrm{g} \cdot \mathrm{l}^{-1}$ of microcystin LR (high concentration of the extract). Control eggs were incubated in toxin-free water. The cumulative concentration of microcystins was $1.3,13.0$ and $130.0 \mu \mathrm{g} \cdot \mathrm{l}^{-1}$, respectively. The tests were finished after 8 days (short-term exposure) and after 30 days (long-term exposure). The tests experiments with high concentration were finished after 8 days because very high mortality of embryos.

Five fish from each group were killed, immediately fixed in Bodian solution and processed using standard methods for histology. Tissue sections $(5 \mu \mathrm{m})$ were stained with haematoxylin-eosin and PAS. Apoptotic cells were detected with TUNEL test. All sections were examined using light microscopy. Liver and kidney tissues were examined, in particular.

\section{Results}

Tests with short-term exposure

No histopathological changes were found both in fish from control and experimental groups except for non-resorbed yolk sacks in the larvae from group exposed to the high concentration of the extract. It means that the development has been retarded in this group (Plate I, Fig. 1).

\section{Tests with long-term exposure}

No changes in liver and kidney were found in the control group. Vacuolar dystrophy of hepatocytes (Plate I, Fig. 2) with damage of nuclei (pyknosis, karyolysis) was found in the group exposed to low concentration of the extract. These changes were found in all sampled larvae. No changes were found in the kidney.

Focal necroses (mainly perivascular) and dystrophic changes of hepatocytes with vacuolisation and nucleic damage (pyknosis, karyolysis, hyperchromatosis, karyorrhexis) were found in the group exposed to the medium concentration of the extract (Plate II, Fig. 3). These changes were found in all sampled larvae. Using TUNEL test for detection of apoptosis apoptotic cells were detected in the liver, mainly in perivascular and interstitial liver tissue (Plate II, Fig. 4). No changes were found in the kidney.

\section{Discussion}

High mortality and retarded development in tests with short-term exposure may be due to encreased energy demand of detoxication processes, as described by Wieg and et al. (1999). The histopathological changes of liver in our study were similar to the changes described in various papers in young and adult fish. Rodger et al. (1994) described the histopathological changes of brown trout (Salmo trutta) associated with the death of water blooms of Anabaena flos-aquae. The changes in liver were characterised by confluent necrosis showing cellular degeneration and loss of obvious cell boundaries. Pyknosis and karyorrhexis of hepatocytes was obvious. Similar changes in liver have been described in different fish species by other authors, e.g. Garcia (1989), Råbergh et al. (1991), Tencalla et al. (1994). Råbergh et al. (1991) described degeneration of kidney tubuli after intraperitoneal application of the lethal dosis of microcystin LR to the carp. Carbis et al. (1996) detected histopathological changes in the gills, in liver and kidney of carp exposed to microcystins by gavage, immersion and intraperitoneal administration. Intraperitoneal inoculation caused necrosis or dosedepended degeneration. Gavaging caused changes in the histopathology of the liver and gills. Cellular degeneration and necrosis occurred in the liver, gills and kidneys when carp were introduced to a tank containing $1.7 \mu \mathrm{g} \cdot \mathrm{ml}^{-1}$ of microcystins. Carbis et al. (1997) studied carps exposed to Microcystis aeruginosa at Lake Mokoan (Australia). The total concentration of the microcystins was approximately $4.0 \mu \mathrm{g} \cdot \mathrm{g}^{-1}$ of the lyophilised scum material. During 
February, March and April the liver histology was characterised by cytoskeletal collapse, cytoplasmic vacuolization, pyknosis, chromatin margination, eosinophilia and widespread hepatocyte atrophy, particularly in areas close to the arterial blood supply in about $66 \%$ of the carp examined. During February and March gill samples were characterised by necrosis, folder lamellar tips and mild epithelial ballooning in about $30 \%$ of the carp examined. Fischer et al. (2000) indicate that hepatocyte necrosis represents primary events in microcystin induced hepatotoxicity in the rainbow trout and that apoptotic cell death seems to be of only secondary nature. Fischer and Dietrich (2000) suggest that, in comparison to the pathological events in salmonids exposed to microcystin, in which a slower development of pathology and primarily necrotic cell death prevails, the pathology in the carp develops rapidly and at lower toxin concentrations. According to them, this is most likely due to a more efficient uptake of toxins, while the mechanism of cell death is primarily apoptosis.

We detected damage of liver in in fish from tests with long term exposure. The degree of damage depended on the concentration of the extract. We did not observe any damage of kidney.

\section{Histopatologie larev kapra (Cyprinus carpio L.) vystavených extraktu sinic}

Cílem práce bylo zjistit histologické změny kapřích embryí a larev vystavených krátkodobě (8 dní) a dlouhodobě (30 dní) hrubému extraktu cyanobakterií s kumulativní koncentrací $130.0 \mu \mathrm{g} \cdot \mathrm{l}^{-1}$ (vysoká koncentrace extraktu) $13.0 \mu \mathrm{g} \cdot \mathrm{l}^{-1}$ (střední koncentrace extraktu) a $1.3 \mu \mathrm{g} \cdot \mathrm{l}^{-1}$ (nízká koncentrace extraktu)) mikrocystinů LR, RR a YR. Koncentraci $130.0 \mu \mathrm{g} \cdot \mathrm{l}^{-1}$ jsme použili pouze krátkodobě. Tkáňové řezy jsme barvili hematoxylin-eosinem a barvením PAS a vyhodnotili pomocí světelné mikroskopie. Apoptotické buňky byly detekovány TUNEL testem. Zejména jsme sledovali jaterní a ledvinnou tkáň. Nenalezli jsme žádné histologické změny u kontrolních a pokusných skupin po krátkodobé expozici, s výjimkou nevstřebaného žloutkového váčku ve skupině s vysokou koncentrací extraktu. Tento nález naznačuje retardovaný vývoj v této skupině. Ve skupině s nízkou koncentrací extraktu a dlouhou expozicí jsme zjistili vakuolární dystrofii hepatocytů s poškozením jader (pyknóza, karyolýza). Fokální nekrózy a dystrofické změny hepatocytů s vakuolizací a poškozením jader (pyknóza, karyolýza, hyperchromatóza, karyorexe) jsme zjistili po dlouhodobé expozici ve skupině vystavené střední koncentraci extraktu. V jaterní tkáni jsme zaznamenali př́ítomnost apoptotických buněk. Nenalezli jsme žádné změny v ledvinné tkáni. Ze sledování vyplývá, že jsme zjistili postižení jater u larvárních stádií kapra obecného vystaveného působení extraktu cyanobakterií v ranných fázích vývoje. Stupeň poškození závisel na koncentraci extraktu.

\section{Acknowledgement}

This work was supported by the internal grant of the University of Veterinary and Pharmaceutical Sciences Brno, by Grant Agentury of Czech Republic (Project No. 524/01/P027) and by Association Flos-aquae.

\section{References}

BEASLEY VR, COOK WO, DAHLEM AM, HOOSER SB, LOVELL AL, VALENTINE WM 1989: Algae intoxication in livestock and waterfowl. Clin Toxicol Vet Clin N Am Food A 5: $345-361$

BLÁHA L, MARŠÁLEK B 2001: Dissolved microcystins in Raw and treated drinking water in the Czech republic. In: Chorus I.ed. Cyanobacterial Toxins, Springer Verlag, Berlin, pp. 212-217

CARMICHAEL WW 1992: Cyanobacteria secondary metabolities the cyanotoxins. A review. J Appl Bacteriol 72: 445-459

CARBIS CR, RAWLIN GT, MITCHELL GF, ANDERSON JW, MCCAULEY I 1996: The histopathology of carp, Cyprinus carpio, L., exposed to microcystins by gavage, immersion and intraperitoneal administration. J Fish Dis 19: 199-207

CARBIS, CR, RAWLIN, GT, GRANT, P, MITCHELL, GF, ANDERSON, JW, MCCAULEY, I 1997: A study of feral carp, Cyprinus carpio L., exposed to Microcystis aeruginosa at Lake Mokoan, Australia, and possible implications for fish health. J Fish Dis 20: 81-91 
ERIKSSON, JE 1990: Toxic peptides from cyanobacteria - characterization and cellular mode of action. Academic dissertation, Åbo Akademi University, 54 p.

ERIKSSON, JE, HÄGERSTRAND, H, ISOMAA, B 1987: Cell selective cytotoxicity of peptide toxin from the cyanobacterium Microcystis aeruginosa. Biochem Biophys Acta 930: 304-610

ERIKSSON, JE, MERILUOTO, JAO, KUJARI, HP, SKULBERG, OM 1988a: A comparison of toxins isolated from the cyanobacteria Oscillatoria agardhii and Microcystis aeruginosa. Comp Biochem Phys C 89: 207-210

ERIKSSON, JE, MERILUOTO, JAO, KUJARI, HP, JAMEL AL-LAYL, K, CODD, GA 1988b: Cellular effects of cyanobacterial peptide toxins. Toxicity Assesment 3: 511-517

ERIKSSON, JE, PAATERO, GIL, MERILUOTO, JAO, CODD, GA, KASS, GEN, NICOTERA, P, ORRENIUS, S 1989: Rapid microfilament reorganization induced in isolated rat hepatocytes by microcystin-LR, a cyclic peptide toxin. Exp Cell Res 185: 86-100

FALCONER, IR, BERESDORF, AM, RUNNEGAR, MTC 1983: Evidence of liver damage by toxin from bluegreen alga Microcystis aeruginosa. J Med Aust 1: 511-514

FALCONER, IR, YEUNG, DSK 1992: Cytoskeletal changes in hepatocytes induced by Microcystis toxins and their relation to hyperphosphorylation of cell proteins. Chem Biol Interact 81: 181-196

FISCHER, WJ, DIETRICH, DR 2000: Pathological and biochemical characterization of microcystin-induced hepatopancreas and kidney damage in carp (Cyprinus carpio). Toxicol Appl Pharm 164: 73-81

FISCHER, WJ, HITZFELD, BC, TENCALLA, F, ERIKSSON, JE, MIKHAILOV, A, DIETRICH, DR 2000: Microcystin-LR toxicodynamics, induced pathology, and immunohistochemical localization in livers of bluegreen algae exposed rainbow trout (Oncorhynchus mykiss). Toxicol Sci 54: 365-373

FISCHER, WJ, GARTHWAITE, I, MILES, CO, ROSS, KM, AGGEN, JB, CHAMBERLIN, AR, TOWERS, NR, DIETRICH, DR 2001: Congener independent immunoassay for microcystins and nodularins. Environ Sci Technol 35: 4849-4856

GARCIA, BO 1989: Toxicity of the cyanobacterium, Microcystis aeruginosa strain 7820 to trout and tilapia: a clinical and histopathological study. M. Sc. Thesis, University of Stirling

LAWTON, LA, EDWARDS, C, CODD, GA 1994: Extraction and high-performance liquid-chromatographic method for the determination of microcystins in raw and treated waters. Analyst 119: 1525-1530

LIU, YD, SONG, LR, LI, XY, LIU, TM 2002: The toxic effects of microcystin-LR on embryo-larval and juvenile development of loach, Misguruns mizolepis Gunthe. Toxicon 40: 395-399

MARŠÁLEK, B, TURÁNEK, J 1996: Biological active substances produced by blue-green algae of water blooms. In: MARŠÁLEK B, et al. (Ed): Water blooms of blue-green algae. Nadatio flos-aquae, Brno (In Czech), pp. 86-100

MARŚÁLEK, B, BLÁHA, L, TURÁNEK, J 2001: Microcystin LR and total microcystins in Czech reservoirs during 1993-1998. In: Chorus I. ed.- Cyanobacterial Toxins, Springer Verlag, Berlin, pp. 56-62

OBEREMM, A, FASTNER, J, STEINBERG, CEW 1997: Effects of microcystin LR and cyanobacterial crude extracts on embryo-larval development of zebrafish (Danio rerio). Water Res 31: 2918-2921

OBEREMM, A, BECKER, J, CODD, GA, STEINBERG, C 1999: Effects of cyanobacterial toxins and aqueous crude extracts of cyanobacteria on the development of fish and amphibians. Environ Toxicol 14: 77-87

RÅBERGH, CMI, BYLUND, G, ERIKSSON, JE 1991: Histopathological effects of microcystin LR, a cyclic peptide toxin from the cyanobacterium (blue-green alga) Microcystis aeruginosa on common carp (Cyprinus carpio L.). Aquat Toxicol 20: 131-146

RODGER, HD, TURNBULL, T, EDWARDS, C, CODD, GA 1994: Cyanobacterial (blue-green algal) bloom associated pathology in brown trout, Salmo trutta L., in Loch Leven, Scotland. J Fish Dis 17: 177-181

RUNNEGAR, MTC, FALCONER, IR 1986: Effect of toxin from the cyanobacterium Microcystis aeruginosa on ultrastructural morphology and actin polymeration in isolated hepatocytes. Toxicon 24: 109-115

TENCALLA, FG, DIETRICH, DR, SCHLATTER, CH 1994: Toxicity of Microcystis aeruginosa peptide toxin to yearling rainbow trout (Oncorhynchus mykiss). Aquat Toxicol 30: 215-224

WIEGAND, C, PFLUGMACHER, S, OBEREMM, A, MEEMS, N, BEATTIE, KA, STEINBERG, CEW, CODD, GA 1999: Uptake and effects of Microcystin - LR on detoxication enzymes of early life stages of the zebra fish (Danio rerio). Environ Toxicol 14: 89-5 
Plate I

Palíková M. et al.: Histopathology ... pp. 253-257
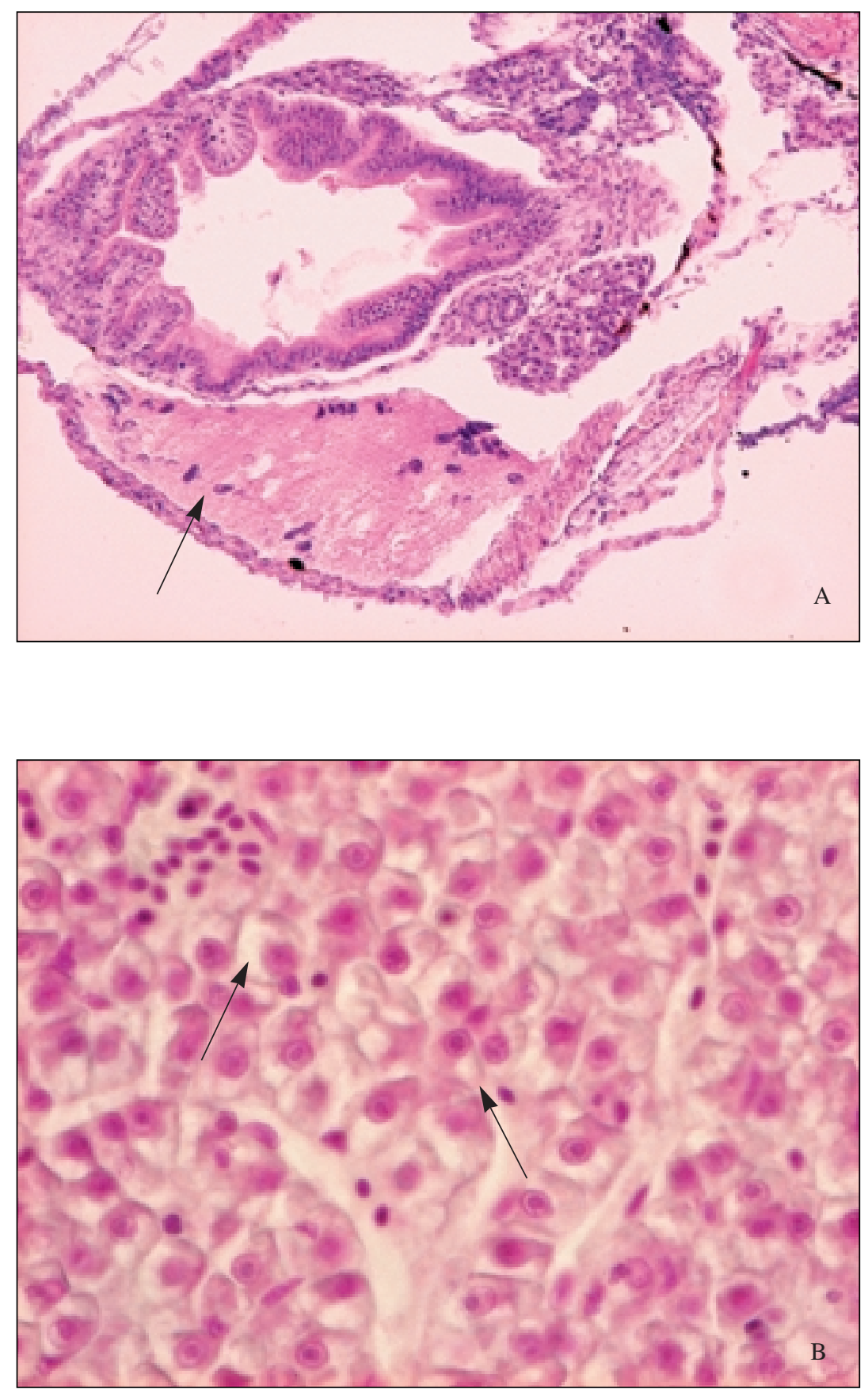

Fig. 1. A. The larva of carp from short exposure. Retardation of development of fish exposed to the high concentration of the extract, non resorbed yolk sack $(\rightarrow \mathrm{H} \& \mathrm{E} \times 100)$.

B. Vacuolar dystrophy of hepatocytes with pyknosis and karyolysis of nuclei in fish with low concentration of the extract and long exposure $(\rightarrow \mathrm{H} \& \mathrm{E} \times 400)$. 
Plate II
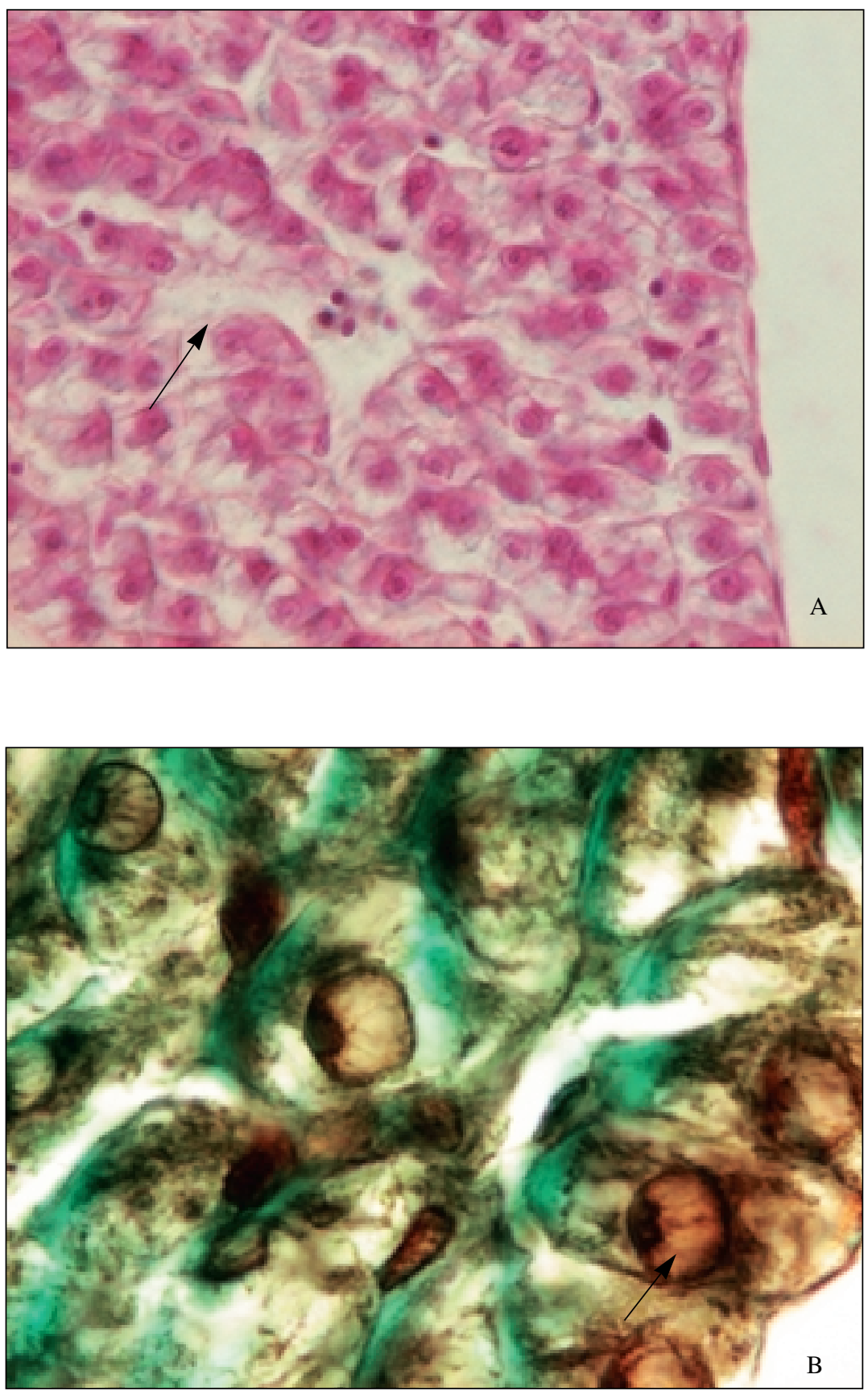

Fig. 2. The liver of carp from long exposure and medium concentration of the extract. A. Perivascular focal necrosis $(\rightarrow \mathrm{H} \& \mathrm{E} \times 400)$. B. Apoptotic cells $(\rightarrow$ TUMEL $\times 1000)$. 